\title{
Effects of waves on helophyte stands: mechanical characteristics of stems of Phragmites australis and Scirpus lacustris
}

\author{
Hugo Coops ${ }^{\text {a, } *}$, Gerard Van der Velde ${ }^{b}$ \\ anstitute for Inland Water Management and Waste Water Treatment (RIZA). P.O. Box 17, 8200 AA Lelystad, \\ The Netherlands \\ ${ }^{b}$ Department of Ecology, Laboratory of Aquatic Ecology, University of Nijmegen, Toernooiveld, 6525 ED \\ Nijmegen. The Netherlands
}

Accepted 18 January 1996

\begin{abstract}
The effects of wave attack on stands of the two species Scirpus lacustris L. and Phragmites australis (Cav.) Trin. ex Steudel were studied in a wave tank, and related to bending and breaking characteristics of the stems. Stands of the two species, growing at a water depth of $0.5 \mathrm{~m}$, were exposed to uniform waves with a height of $0.23 \mathrm{~m}$ high and a wave period of $1.9 \mathrm{~s}$. Mean stem height and density were reduced strongly in the $S$. lacustris stands after wave attack. The effects of wave attack on mean stem height and density of $P$. australis stands were much less pronounced. In both species, critical breaking force and flexural stiffness of stems increased with individual stem height. Bending stiffness was much lower in $S$. lacustris stems (mean $E=0.25$ $\mathrm{GPa}$ ) than in $P$. australis stems (mean $E=4.93 \mathrm{GPa}$ ). Seasonal variation in stiffness was observed in $P$. australis stems but not in $S$. lacustris; for $P$. australis, $E$ was lower in February (dead standing stalks) and June (young shoots), than in August. Stands of $P$. australis withstand exposure to waves hetter than $S$. lncustris stands as the result of a higher bending stiffness of the stems and a lower susceptibility to breaking under mechanical stress. Therefore, $S$. lacustris can grow in waterside helophyte fringes when wave exposure is moderate or absent, but cannot survive at highly wave-exposed shores.
\end{abstract}

Keywords: Helophytes; Flexural stiffness; Fracture; Phragmites; Scirpus; Waves

\footnotetext{
"Corresponding author.
} 


\section{Introduction}

Exposure to waves may affect emergent plant distribution along the banks of channels, rivers and lakes. Wave forces may impose restrictions on growth and eventually result in deterioration of plants growing on banks (Bonham, 1983). Helophyte species may show different responses to water motion. The survival of their stands is related to the mechanical resistance of the stems against wave forces.

The amount to which helophytes can withstand exposure to waves is to a large extent determined by mechanical properties of the stems. Damage to stems depends on their bending stiffness. Between-species differences in mechanical characteristics of stems may play a role in generating differences in the zonation of emergent vegetation between locations with varying wave exposure.

Mechanical characteristics of stems can be measured in a relatively straightforward manner in bending trials (Szczepanski, 1970; Binz-Reist, 1989). In the present study the effects of mechanical loading on stems of two helophyte species, Phragmites australis (Cav.) Trin. ex Steudel and Scirpus lacustris L., were compared. The retreat of these species from the lower reaches of many shores has been ascribed in several cases to increased impact of waves (Ostendorp, 1989). Helophytes, with S. lacustris in particular, have suffered from the direct and indirect effects of increased wave action in the Netherlands (Coops et al., 1996).

Differences between the mechanical characteristics of $P$. australis and $S$. lacustris stems may also contribute to the explanation of distributional differences between the species along water depth and exposure gradients, which have been observed in previous field studies (Coops et al., 1991; Coops et al., 1994). Our hypothesis was that $P$. australis has stiff and strong stems, allowing it to grow at shallow exposed areas where turbulence may be high, whereas $S$. lacustris has more flexible stems, allowing it to grow at greater water depths in the zonation, and move with the incoming waves; plants with weaker stems are at a disadvantage in shallow water.

\section{Materials and methods}

Stands of $P$. australis and S. lacustris wcre grown from 1990 to 1993 in an outdoor wave tank at De Voorst (The Netherlands), in separate $4 \mathrm{~m} \times 2.55 \mathrm{~m}$ sections that were permanently flooded to a depth of $0.50 \mathrm{~m}$. Four sections were exposed to periodical wave attack $(3 \times 8 \mathrm{~h}$ every 4 weeks between February and October; wave period $1.9 \mathrm{~s}$, wave length $4.80 \mathrm{~m}$, wave height $0.10 \mathrm{~m}$ between August 1991 and October 1991, and $0.23 \mathrm{~m}$ between February 1992 and October 1993). Two other sections planted with each of the species were used as unexposed controls (Coops et al., 1996).

In each section, all individual lengths of emergent stems (distance from stem base to the tip of the longest leaf) were measured in nine $1.0 \mathrm{~m} \times 0.5 \mathrm{~m}$ quadrats in June and August 1993 and the frequency distributions of stem lengths in classes of $0.25 \mathrm{~m}$ were determined. The difference in the length distribution between wave exposed and control 

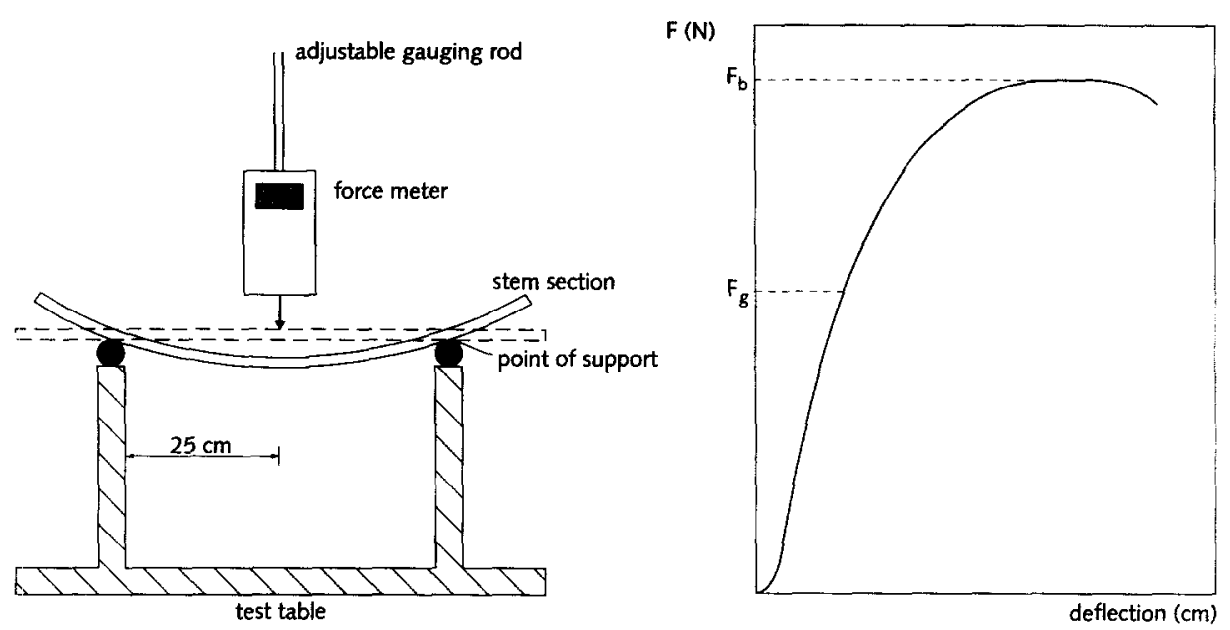

Fig. 1. (a) Schematic representation of the device used to determine strength and flexibility of stalks. The stalks were positioned horizontally over the two supports, while a vertical force was applied by moving the gauging rod downwards, thereby increasing the force exerted on the centre of the stalk. (b) Schematic form of a deflection-applied force curve. Critical forces for yield $\left(F_{g}\right)$ and breaking $\left(F_{b}\right)$ are indicated along the abscissa.

stands was tested for each species and sampling period separately using the Kolmogorov-Smirnov test.

A number of randomly selected emergent stems of over $0.50 \mathrm{~m}$ height were harvested from the sections in June 1993 (Week 23, living stems of $P$. australis $(n-60)$ and $S$. lacustris $(n=51)$ ) and August 1993 (Week 36, living stems of P. australis $(n=56)$ and S. lacustris $(n=44)$ ). The stems were cut off at the stem base, and stem length and external diameter at the stem base were determined. The internal diameter of the hollow stems of $P$. australis was measured as well in order to calculate the stem wall thickness. Dry weight biomass (after drying for $24 \mathrm{~h}$ at $105^{\circ} \mathrm{C}$ ) was determined for each stem.

Thirty-two stems of $P$. australis harvested in February 1993 (Week 9) were sampled additionally for determination of the same parameters for the standing dead stems in winter.

Bending tests were done within $1 \mathrm{~h}$ after cutting the stem to avoid effects of drying, prior to the destructive determination of biomass. Basal stem sections of approximately $0.60 \mathrm{~m}$ length were tested in a bending device (Fig. 1a). Each stem section was positioned horizontally over two supports which were exactly $0.50 \mathrm{~m}$ apart. A vertical force was applied to the middle of the stem section. The force was increased gradually by lowering a manually adjustable gauging rod (precision $0.1 \mathrm{~mm}$ ), fitted with a force meter (Aikoh cpu digital force gauge 7500, Aikoh Engineering Co. Ltd., Osaka; maximum load $2 \mathrm{~kg}$ ). The critical forces at the yield point $\left(F_{g}\right)$ and at the breaking point $\left(F_{b}\right)$ and the corresponding deflections ( $u_{g}$ and $u_{b}$, respectively) were read from the graphs plotting applied force and deflection (Fig. 1b). 
The flexural stiffness of each individual stem section was calculated using the appropriate formula (Denny, 1988; Binz-Reist, 1989)

$$
E I=\frac{l^{3}}{48} \cdot \frac{F_{g}}{u_{g}}\left[\mathrm{~N} \mathrm{~m}^{2}\right]
$$

where $E I=$ flexural stiffness, $l=$ length of stem section $(0.50 \mathrm{~m}), F_{g}=$ force at yield point, $u_{g}$ deflection corresponding to $F_{g}$.

After calculating

$$
l=\frac{\pi}{4}\left(R^{4}-R_{i}^{4}\right)\left[\mathrm{m}^{4}\right]
$$

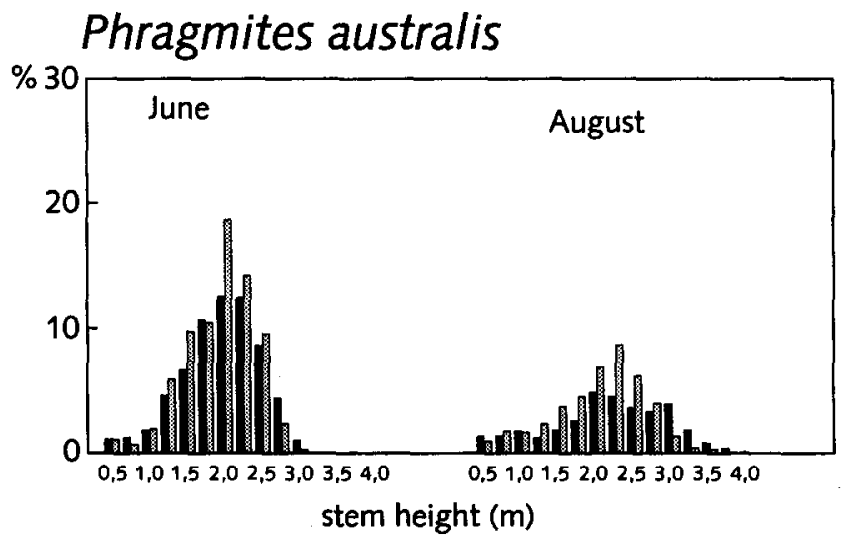

Scirpus lacustris

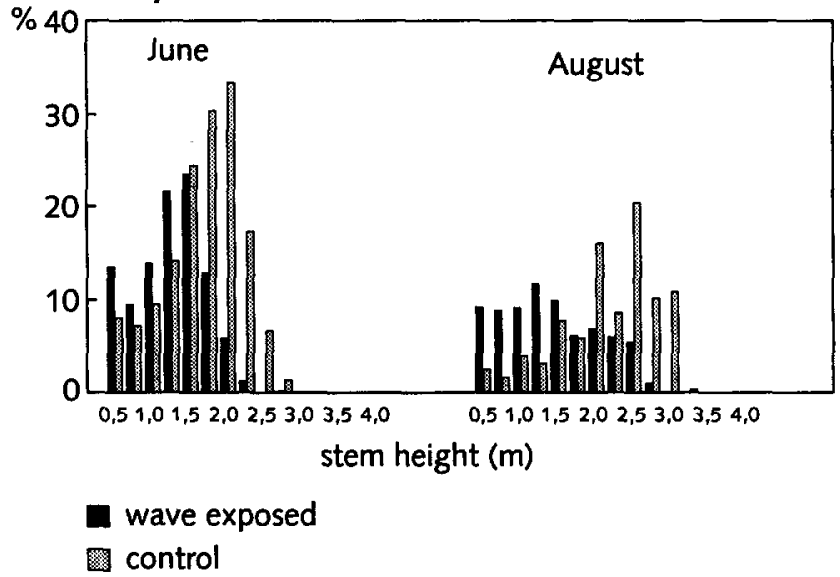

Fig. 2. Frequency distributions of emergent stem heights in helophyte stands. (a) $P$. australis in June 1993 (wave exposed, $n=1168$; unexposed control, $n=672$ ) and in August 1993 (wave exposed, $n=606$; unexposed control, $n=388$ ); (b) $S$. lacustris in June 1993 (wave exposed, $n=1861$; unexposed control, $n=1388$ ) and in August 1993 (wave exposed, $n=1355$; unexposed control, $n=828$ ). 
where $I=$ second moment of area, $R=$ stem radius, $R_{i}=$ stem internal radius in hollow stems (equal to zero in the case of $S$. lacustris), the bending stiffness ( $E$, in $\mathrm{GPa}\left(=10^{9}\right.$ $\mathrm{N} \mathrm{m}^{-2}$ ) could be determined using Eq. (1) and Eq. (2).

The correlations $\left(R^{2}\right)$ between morphometric and mechanical parameters were calculated. Differences between the breaking forces of the two species were tested using analysis of covariance with stem length and diameter as covariates.

\section{Results}

The stem height frequency distributions showed much more pronounced differences between wave-exposed and sheltered conditions for $S$. lacustris than for $P$. australis (Fig. 2). In $P$. australis the median stem lengths in June 1993 were $209.5 \mathrm{~cm}$ in the unexposed control and $211 \mathrm{~cm}$ in the exposed sections (Kolmogorov-Smirnov test, $Z=1.52, P<0.05$ ), whereas in August median stem lengths were $223 \mathrm{~cm}$ in the unexposed control and $235 \mathrm{~cm}$ in the exposed sections (Kolmogorov-Smirnov test, $Z=2.68, P=0.001$ ). In June 1993 median stem lengths of $S$. lacustris were $183 \mathrm{~cm}$ in the unexposed control sections, and $141 \mathrm{~cm}$ in the wave exposed sections (Kolmogorov-Smirnov test, $Z=10.96, P<0.001$ ). In August the median lengths of stems were $238 \mathrm{~cm}$ in the unexposed control sections, and $146 \mathrm{~cm}$ under wave exposed conditions (Kolmogorov-Smirnov test, $Z=10.42, P<0.001$ ).

Neither $P$. australis nor $S$. lacustris showed a significant difference in any of the parameters measured on the stems sampled between the wave exposed and control sections; hence morphometric and mechanical data of the stems could be pooled for each of the species at the harvesting dates (Table 1).

Overall, $P$. australis stems were stiffer (mean of all measurements $4.93 \mathrm{GPa}$ ) than $S$. lacustris stems (mean $0.25 \mathrm{GPa}$ ) (Table 1). A seasonal effect was observed in $P$. australis, as the bending stiffness was higher in August compared to February and June. $P$. australis stems were stiffer than $S$. lacustris stems of the same length, resulting in smaller deflections when an external force was applied (Fig. 3b). For P. australis, the

Table 1

Density of stems in plots, stem length, stem diameter, stem wall thickness, and the mechanical stem characteristics EI and E of Phragmites australis and Scirpus lacustris in June and August 1993

\begin{tabular}{llllll}
\hline & \multicolumn{2}{l}{ Phragmites australis } & & \multicolumn{2}{l}{ Scirpus lacustris } \\
\cline { 2 - 3 } \cline { 5 - 6 } \cline { 5 - 6 } & June & August & & June & August \\
\hline Living stem density $\left(\mathrm{m}^{-2}\right)$ & $70.6 \pm 6.8$ & $45.3 \pm 3.7$ & & $144.0 \pm 17.3$ & $83.6 \pm 12.2$ \\
Total stem density $\left(\mathrm{m}^{-2}\right)$ & $166.5 \pm 11.2$ & $139.5 \pm 13.0$ & & $144.0 \pm 17.3$ & $83.6 \pm 12.2$ \\
Stem length $(\mathrm{m})$ & $1.81 \pm 0.11$ & $2.32 \pm 0.17$ & & $1.69 \pm 0.11$ & $2.17 \pm 0.15$ \\
Stem diameter $(\mathrm{m})$ & $0.0060 \pm 0.0004$ & $0.0068 \pm 0.0003$ & & $0.0088 \pm 0.0005$ & $0.0112 \pm 0.0008$ \\
Stem wall thickness $(\mathrm{m})$ & $0.0014 \pm 0.0002$ & $0.0012 \pm 0.0001$ & & n.d. & n.d. \\
Stem dry weight $(\mathrm{g})$ & $6.22 \pm 1.43$ & $12.21 \pm 2.13$ & & $\mathbf{2 . 7 4} \pm 0.38$ & $4.58 \pm 0.69$ \\
EI $\left(\mathrm{N} \mathrm{m} \mathrm{m}^{2}\right)$ & $0.22 \pm 0.06$ & $0.55 \pm 0.16$ & & $0.08 \pm 0.02$ & $0.22 \pm 0.06$ \\
$E(\mathrm{GPa})$ & $3.62 \pm 0.72$ & $6.93 \pm 1.58$ & & $0.24 \pm 0.04$ & $0.26 \pm 0.05$ \\
\hline
\end{tabular}

EI, bending stiffness; E, elastic modulus. Mean values \pm 2 SE are shown. 


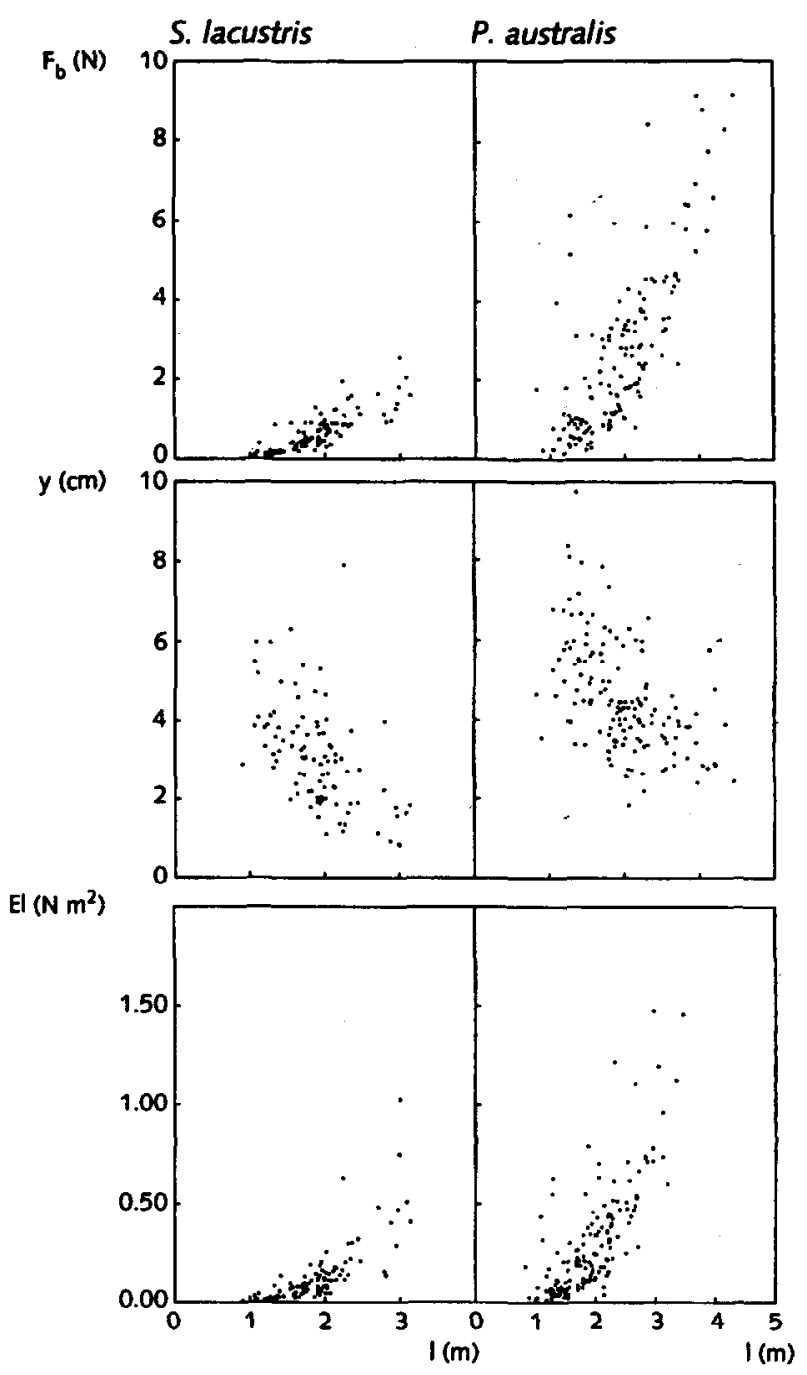

Fig. 3. Relationship between stem length $(\mathrm{cm})$ and (a) critical breaking force $\left(F_{b}, \mathrm{~N}\right)$, (b) maximal deflection $\left(u_{b}, \mathrm{~cm}\right)$, and (c) flexural stiffness $\left(E l, \mathrm{~N} \mathrm{~m}^{2}\right)$, for $P$. australis and $S$. lacustris stems.

bending stiffness of stems grown under wave-exposed conditions did not differ significantly from stems in the control sections.

Standing stems of $S$. lacustris decayed during the winter period, so in February only a short stubble was present; in contrast, erect dead stems remained over several growing seasons in the $P$. australis stands. The mean length of the remaining parts of the stems was $1.75 \pm 0.18 \mathrm{~m}$, external diameter $0.0073 \pm 0.0006 \mathrm{~m}$, stem wall thickness 0.0011 土 $0.0002 \mathrm{~m}$. The bending stiffness of these dead culms was $3.90 \pm 1.38 \mathrm{GPa}$, which was lower than those sampled in August and comparable to those sampled in June. The mean 
Table 2

Correlation matrix of mechanical and population parameters

\begin{tabular}{|c|c|c|c|c|c|c|c|c|c|}
\hline & $F_{g}$ & $F_{b}$ & $\boldsymbol{u}$ & $E$ & $I$ & $E I$ & $l$ & $d$ & $W$ \\
\hline \multicolumn{10}{|c|}{ Phragmites australis } \\
\hline$F_{g}$ & 1.000 & & & & & & & & \\
\hline$F_{b}$ & $0.973^{*} *$ & 1.000 & & & & & & & \\
\hline$u$ & $-0.430^{* *}$ & $-0.432^{* *}$ & 1.000 & & & & & & \\
\hline$E$ & $0.549^{* *}$ & $0.463 * *$ & $-0.256 \mathrm{~ns}$ & 1.000 & & & & & \\
\hline$I$ & $0.157 \mathrm{~ns}$ & $0.259 \mathrm{~ns}$ & $-0.08 \operatorname{lns}$ & $-0.366^{* *}$ & 1.000 & & & & \\
\hline$E I$ & $0.946^{* *}$ & $0.961^{* *}$ & $-0.487^{* *}$ & $0.404^{* *}$ & $0.290^{*}$ & 1.000 & & & \\
\hline$l$ & $0.755^{* *}$ & $0.771 * *$ & $-0.565^{* *}$ & $0.480^{* *}$ & $0.081 \mathrm{~ns}$ & $0.705^{* *}$ & 1.000 & & \\
\hline$d$ & $0.304^{*}$ & $0.396^{* *}$ & $-0.245 \mathrm{~ns}$ & $-0.347^{* *}$ & $0.893^{* *}$ & $0.424^{* *}$ & $0.235 \mathrm{~ns}$ & 1.000 & \\
\hline$W$ & $0.891^{* *}$ & $0.915^{* *}$ & $-0.466^{*}$ & $0.506^{* *}$ & $0.177 \mathrm{~ns}$ & $0.873^{* *}$ & $0.869^{* *}$ & $0.343^{* *}$ & $1: 000$ \\
\hline
\end{tabular}

Scirpus lacustris

$F_{g} \quad 1.000$

$F_{b} \quad 0.876^{* *} \quad 1.000$

u $-0.509^{* *}-0.397^{* *} \quad 1.000$

E $\quad-0.091 \mathrm{~ns} \quad-0.106 \mathrm{~ns} \quad-0.004 \mathrm{~ns} \quad 1.000$

I $\quad 0.693^{* *} \quad 0.794^{* *}-0.451^{* *}-0.293 \mathrm{~ns} \quad 1.000$

EI $\quad 0.836^{* *} \quad 0.871^{* *}-0.534^{* *}-0.048 \mathrm{~ns} \quad 0.896^{* *} 1.000$

$l \quad 0.637^{* *} 0.763 * *-0.507 * * 0.006 \mathrm{~ns} \quad 0.660^{*} * 0.717^{*} * 1.000$

$d \quad 0.724^{* *} \quad 0.827^{* *}-0.495^{* *}-0.435^{* *} 0.923^{* *} 0.831^{* *} 0.683^{* *} 1.000$

$W \quad 0.674^{* *} \quad 0.821^{* *}-0.445^{* *} \quad-0.200 \mathrm{~ms} \quad 0.849^{* *} 0.814^{* *} 0.777^{* *} 0.830^{* *} 1.000$

$R^{2}$, Pearson correlation coefficients; $F_{g}$, critical force of reversible bending $(\mathrm{N}) ; F_{b}$, breaking force $(\mathrm{N}) ; u$, maximum deflection $(\mathrm{m}) ; E$, bending stiffness $(\mathrm{GPa}) ; I$, second moment of area $\left(\mathrm{m}^{4}\right) ; E I$, flexural stiffness (N $\left.\mathrm{m}^{2}\right) ; l$, stem length $(\mathrm{m}) ; d$, stem basal external diameter $(\mathrm{m}) ; W$, stem dry weight ( $\mathrm{g}$ dry weight). Significance: ns not significant, ${ }^{*} P<0.01,{ }^{* *} P<0.001$.

stiffness of the dead stems probably represented the range of bending stiffnesses of stems in various stages of degradation.

Various correlations were found between morphological and mechanical parameters of stems of both $S$. lacustris and $P$. australis (Table 2). There was a highly significant correlation between stem length and diameter in $S$. lacustris, but such a correlation was lacking in $P$. australis. Critical bending and breaking forces varied within the stands, in relation to both stem length and diameter (Fig. 3). Without the effect of stem length and diameter, $P$. australis stems had a significantly higher critical breaking force than $S$. lacustris stems (ANCOVA, $F=61.760, P<0.001$ ). Furthermore, $P$. australis stems showed a significantly higher $E I$ than $S$. lacustris stems (ANCOVA, $F=42.553$, $P<0.001$ ).

\section{Discussion}

Strength and flexibility of emergent plant stems may vary as a result of differences between species in anatomical and morphological structures (Wainwright et al., 1976; Speck et al., 1990), but may also vary seasonally according to the growth stage of the plant (Ahlgrimm, 1979; Vincent, 1983). 
Stems break when the wave force on the submerged parts exceeds the critical breaking force. Since pressure drag is the major component of the forces generated by orbital water movement under waves (Denny, 1988), breaking of individual stems may be determined by the drag force generated at the water velocity. The maximum water velocities of $>0.50 \mathrm{~m} \mathrm{~s}^{-1}$ that occurred under the $0.23 \mathrm{~m}$ high waves (Coops et al., 1996) apparently were sufficient for the fracture and uprooting of $S$. lacustris, but insufficient to cause damage to the $P$. australis stands. Intra- and inter-specific differences in stem anatomy may help to explain different responses (Wainwright et al., 1976). Bundles of sclerenchyma cells are abundant in the tissue of $P$. australis stems (Rodewald-Rudescu, 1974). The proportion of sclerenchyma fibres and their water content determine the strength of stems (Moustafa et al., 1968; Vincent, 1991; Zebrowski, 1992). The remains of this tissue support the stem even after its death, so that unlike $S$. lacustris, standing dead $P$. australis stems can remain for several years.

Stems may support each other and divert critical forces to the entire stand, which is a form of 'framework-like' protection (Wainwright et al., 1976; Spatz et al., 1990). Thus, high stem densities might be advantageous to helophyte stands growing in the wave-exposed zone. Young shoots, which are most susceptible to mechanical loading, may be protected by the surrounding stems. Consequently, newly emerging $P$. australis shoots in the spring profit from the remaining dead stalks which provide a growth support.

In the course of the growth season, new stems develop rather regularly in S. lacustris (Ondok, 1972), resulting in a strong correlation between stem length and stem diameter. In $P$. australis such a correlation was lacking, which may be due to the development, in addition to the 'normal' stems, of very thin secondary stems that appear after the main stems have been damaged (Haslam, 1969). In the latter case, the plants compensate for stem loss by new offshoot formation from dormant rhizome buds; however, few buds sprout in $P$. australis after the summer period (Haslam, 1969), resulting in detrimental effects of critical wave attack particularly in the high and late growth season. Likewise, repeated critical wave attack events may be destructive for the vegetation fringe.

Wave forces may override the impact of wind in more or less deep water, although wind forces provide the predominant mechanical stress for vertically growing terrestrial plants (Grace, 1988; Niklas, 1992; Speck et al., 1990). In contrast to wind forces, waves generate an oscillating stress on plant stems. Forces due to floating litter and algal mats moving with the waves impose an additional stress on helophyte stems (Binz-Reist, 1989; Ostendorp, 1995).

Both stem density and mean stem length were reduced in wave-exposed stands of $S$. lacustris. In contrast, a small but significant positive effect of wave exposure on mean stem length was found for $P$. australis. The lower stem density in $P$. australis due to the loss of small stems may have resulted in taller individual stems (Mook and Van der Toorn, 1982; Granéli, 1987).

Seasonal variations in stiffness may be the result of increasing shoot age and decreasing vitality towards the end of the growth season (Ahlgrimm, 1979; Vincent, 1983). In our study, we found a higher bending stiffness in August compared to June for $\boldsymbol{P}$. australis, but not for $S$. lacustris. The stem strength of $\boldsymbol{P}$. australis has been subject to several studies (Tobler, 1943; Boar and Crook, 1985; Binz-Reist, 1989, Hosner et al., 1990). Most were aimed at the relationship between stem length and sclerenchymatic 
tissue content, both of which may increase between subsequent sampling periods within a year.

Jaffe (1980) found that Festuca arundinacea Schreber stems which were moved continuously tended to increase the proportion of strengthening elements in their stems. However, the current study failed to demonstrate any increased strength in either $P$. australis or $S$. lacustris stems developing under wave-exposed conditions compared to those in the control sections.

Plants may follow either of two strategies of stem development to cope with the wave-exposed environment, developing either stiff and strong stems, or flexible and stretchy stems (Koehl, 1979; Koehl, 1982; Brewer and Parker, 1990). Which is the more suitable adaptation for a species may be determined by the hydrodynamic environment (wave height, water depth, bank slope).

Plants with hollow, tube-like stems, such as $P$. australis, combine a relatively high stiffness with a low biomass investment (Wainwright et al., 1976; Schulgasser and Witztum, 1992). However, hollow stems carry a risk of buckling. This risk might be reduced in $P$. australis by the nodal stabilisation in the stem (Spatz et al., 1990). In addition, fracture properties of gramineous stems vary depending on which part of the stem is loaded (Wright and Illius, 1995). Due to tapering of the stem and the position of nodes, bending properties of the submerged part of the plant are determined not only by stem diameter.

Differences in mechanical behaviour of the two species under wave stress might be the result of contrasting responses of growth forms to the wave-exposed environment. Aquatic organisms living in shallow water should be 'stiff and strong' and be able to resist turbulently moving water, whereas organisms living in deeper water, where unbroken waves occur, would be advantaged by a 'flexible and stretchy' growth form (Koehl, 1979; Koehl, 1982). Brewer and Parker (1990) observed such patterns among submerged macrophytes growing in lakes. Accordingly, field experiments have suggested that the two respective growth forms might be distinguished in the 'deep' water species $S$. lacustris and the 'shallow' water species $P$. australis, respectively (Coops et al., 1994). As the result of having stiffer and stronger stems, $P$. australis appeared to withstand wave attack in shallow water much better than S. lacustris. However, there is no evidence that $S$. lacustris stems are more tolerant of waves in deeper water because they do not show a greater flexibility than $P$. australis. This is reflected in distribution patterns of the species along water depth / exposure gradients. $P$. australis is often the dominant helophyte species in the zone of its optimal growth $(0-50 \mathrm{~cm}$ water depth), at both sheltered and exposed sites. S. lacustris may grow at lower levels (up to $100 \mathrm{~cm}$ water depth), but is absent from highly exposed shorelines (Coops et al., 1991).

\section{Acknowledgements}

We gratefully acknowledge the support given to the research by Rijkswaterstaat, Road and Hydraulics Department, and Delft Hydraulics, as well as the assistance by Noël Geilen and others during the experiment. 


\section{References}

Ahlgrimm, H.J., 1979. Der Einfluss verschiedener Witterungsfaktoren auf die Entwicklung von Grashalmen (Phleum pratense) und ihre Wirkung auf die Halmfestigkeit. Angew. Bot., 53: 161-173.

Binz-Reist, H.R., 1989. Mechanische Belastbarkeit natürlicher Schilfbestände durch Wellen, Wind und Treibzeug. Veröff. Geobot. Inst. Eidg. Tech. Hochschule, Stiftung Rübel, Zürich, nr. 101, 536 pp.

Boar, R.R. and Crook, C.E., 1985. Investigations into the causes of reedswamp regression in the Norfolk Broads. Verh. Int. Ver. Limnol., 22: 2916-2919.

Bonham, A.L, 1983. The management of wave-spending vegetation as bank protection against boat wash. Landscape Plann., 10: 15-30.

Brewer, C.A. and Parker, M., 1990. Adaptations of macrophytes to life in moving water: upslope limits and mechanical properties of stems. Hydrobiologia, 194: 133-142.

Coops, H., Boeters, R. and Smit, H., 1991. Direct and indirect effects of wave attack on helophytes. Aquat. Bot., 41: 333-352.

Coops, H., Geilen, N. and Van der Velde, G., 1994. Distribution and growth of the helophyte species Phragmites australis and Scirpus lacustris in water depth gradients in relation to wave exposure. Aquat. Bot., 48: 273-284.

Coops, H., Geilen, N., Verheij, H., Boeters, R. and Van der Velde, G., 1996. Interactions between waves, bank erosion and emergent vegetation: an experimental study in a wave tank. Aquat. Bot., 53: 187-198.

Denny, M.W., 1988. Biology and the Mechanics of the Wave-swept Environment. Princeton University Press, Princeton, NJ.

Grace, J., 1988. Plant response to wind. Agric. Ecosyst. Environ., 22/23: 71-88.

Granéli, W., 1987. Shoot density regulation in stands of reed, Phragmites australis (Cav.) Trin. ex Steudel.. Arch. Hydrobiol. Beih. Ergeb. Limnol., 27: 211-222.

Haslam, S.M., 1969. The development of shoots in Phragmites communis Trin. Ann. Bot., 33: 695-709.

Hosner, E., Janauer, G.A. and Haberl, R., 1990. Biometrie und mechanische Eigenschaften von Schilf an künstlich geschaffenen und natürlichen Standorten. Landschaftsentwickl. Umweltforsch., 71: 198-199.

Jaffe, M.J., 1980. Morphogenetic responses of plants to mechanical stimulation strcss. BioScience, 30: 239-243.

Koehl, M.A.R., 1979. Stiffness or extensibility of intertidal algae: a comparative study on modes of withstanding wave action. J. Biomech., 12: 6-34.

Koehl, M.A.R., 1982. The interaction between moving water and sessile organisms. Sci. Am., $247: 110-122$.

Mook, J.H. and Van der Toorn, J., 1982. The influence of environmental factors and management on stands of Phragmites australis, II. Effects on yield and its relationships with shoot density. J. Appl. Ecol., 19: 501-517.

Moustafa, S.M.A., Stout, B.A. and Bradley, W.A., 1968. Elastic and inelastic stability of a biological structure. J. Agric. Eng. Res., 13: 64-82.

Niklas, K.J., 1992. Plant Biomechanics: an Engineering Approach to Plant Form and Function. Chicago University Press, Chicago, IL.

Ondok, J.P., 1972. Vegetative propagation in Scirpus lacustris L.. Biol. Plant., 14: 213-218.

Ostendorp, W., 1989. 'Dic-back' of reeds in Europe: a critical review. Aquat. Bot., 35: 5-26.

Ostendorp, W., 1995. Estimation of mechanical resistance of lakeside Phragmites stands. Aquat. Bot., 51: 87-101.

Rodewald-Rudescu, L., 1974. Das Schilfrohr, Phragmites communis Trinius. Binnengewässer, 27: 1-302.

Schulgasser, K. and Witztum, A., 1992. On the strength, stiffness and stability of tubular plant stems and leaves. J. Theor. Biol., 155: 497-515.

Spatz, H.C., Speck, T. and Vogellehner, D., 1990. Contributions to the biomechanics of plants. II. Stability against local buckling in hollow plant stems. Bot. Acta, 103: 123-130.

Speck, T., Spatz, H.C. and Vogellehner, D., 1990. Contributions to the biomechanics of plants. I. Stabilities of 
plant stems with strengthening elements of different cross-sections against weight and wind forces. Bot. Acta, 103: 111-122.

Szczepanski, A., 1970. Methods of morphometrical and mechanical characteristics of Phragmites communis Trin.. Pol. Arch. Hydrobiol., 17: 329-335.

Tobler, F., 1943. Stengelbau, Festigkeits- und Verwertungsunterschiede beim Schilfrohr (Phragmites commu nis Trin.). Angew. Bot., 25: 165-177.

Vincent, J.F.V., 1983. The influence of water content on the stiffness and fracture properties of grass leaves. Grass Forage Sci., 38: 107-114.

Vincent, J.F.V., 1991. Strength and fracture of grasses. J. Mater. Sci., 26: 1947-1950.

Wainwright, S.A., Biggs, W.D., Currey, J.D. and Gosline, J.M., 1976. Mechanical Design in Organisms. Edward Amold, London.

Wright, W. and Illius, A.W., 1995. A comparative study of the fracture properties of five grasses. Funct. Ecol., 9: 269-278.

Zebrowski, J., 1992. Complementary patterns of stiffness in stem and leaf sheaths of Triticale. Measurements of ultrasound velocity. Planta, 187: 301-305. 